1979 , increasing by only 2 per cent. One explanation of this curious price insensitivity is that potential oil producers are waiting until the price of "new" oil is decontrolled towards the second half of 1981 .

The economic consequences of this changing pattern of consumption are plain to see. The three major automobile manufacturers are in the throes of launching their newest small cars - Ford unveiled its new Escort last week - with apprehension and despondency. It the cars do not sell, consumers will buy imported cars and the auto industry will collapse still further. But the profitability of small cars is not nearly as great as that of the old gas-guzzlers.

Using the standard relationship but on the assumption that coal production will continue rapidly to increase, the American Petroleum Institute is now guessing that by 1990 oil consumption in the United States will decline to an average 8-9 million barrels a day, with rather less than half of this imported. Even this estimate may be conservative, for the impending decontrol of petroleum prices may be an unexpected stimulus to drilling. Since the decontrol of natural gas prices during 1979, proven reserves of natural gas have increased more quickly than in the previous decade.

\section{Romanian energy}

\section{Partners to-be}

Romanian President Nicolae Ceausescu has found the answer to current and future problems of the development, efficient and economic use of raw materials and energy resources, according to the leading Party newspaper Scinteia. Reviewing the latest volume in the series "From the Economic Thinking of President Nicolae Ceausescu", Scinteia points out that the President was interested in the problem even before the energy crisis. This is, perhaps, not surprising as Romania, once so oil-rich that an oil-rig was depicted on the state coat of arms, has now sunk to the status of a net oil importer.

Judging from the review Ceausescu's book Energy and Raw Materials Resources (not yet available in the West) seems to reiterate the draft directives for the 1981-85 five-year plan and the long-term guidelines till 1990, recently accepted by the Joint Plenary Meeting of the Central Committee of the Romanian Communist Party and the Supreme Council of Economic and Social Development.

These guidelines provide for a multilateral energy strategy, to include: the expansion of geological prospecting throughout the country and the Black Sea continental shelf, the speeding up of hydroelectric projects, so that the 30 per cent exploitation of hydroelectric potential of 1980 will reach 45 per cent in 1985,65 per cent in 1990 and 100 per cent in the year 2000 , utilization of low grade and less accessible fuels such as shale, and the expansion of the nuclear energy programme (660 MW capacity by 1985 , $3,960 \mathrm{MW}$ by 1990 and $10,000 \mathrm{MW}$ by 2000).

Considerable emphasis is also to be placed on conservation, recycling and what looks remarkably like energy rationing described by official policy hand-outs as "fixing rational ceilings on heating and lighting". Finally, Romanian scientists, whose work has been more firmly harnessed to the needs of the economy than in any other socialist country, will take part in wide-ranging interdisciplinary research to capitalize on the country's geothermal, Sun, wind and tidal resources, as well as biomass conversion. According to the directives, by the year 2000 these resources should account for some 20 per cent of Romania's energy production (by then nuclear energy will have reached 17 per cent).

Vera Rich

\section{Rural communities}

\section{Living now}

What sort of society could the future inhabitants of rural areas find themselves living in? A recent idea for a rural community for the future has come from the Dartington Hall Trust in South Devon, England in the form of a model village built on a scale of 1:250. Recognizing, no doubt, that the future can never be planned by the past, the Dartington model has been designed more as an "exercise in the imagination" than as a blueprint for a real village.

Thinking about the future of rural communities fits well into the work of the Dartington Trust, which was set up in the 1920 s with the wealth of Leonard and Dorothy Elmhirst to bring back life to rural communities which has been depleted during the industrialization of the nineteenth and twentieth centuries. Most of Dartington's work consists of encouraging small industries, not necessarily associated with rural life, and cultural and educational activities in the countryside of Devon. Its latest venture, however, is more theoretical. According to Maurice Ash, the Trust's chairman, the model village is an

Dream in balsa wood

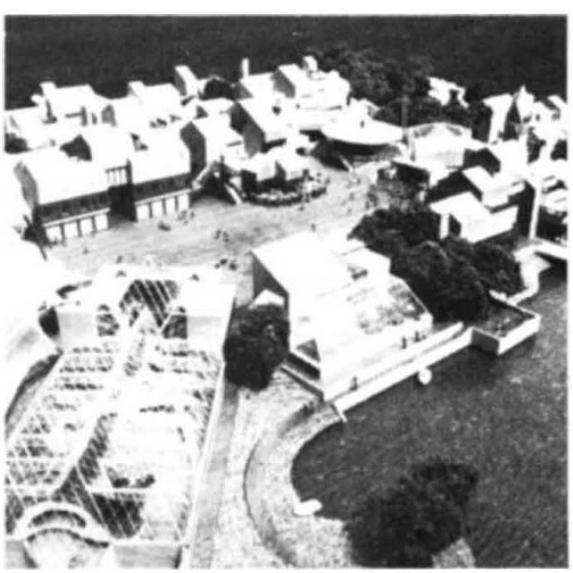

attempt to "speak a new language" by thinking differently about the world in terms of qualities rather than quantities.

That is not to say, however, that the "high" technology of the industrialized world has been ignored. The idea, according to Andrew Page, the brains behind the model, is to achieve a marriage of the microelectronics and green (ecological) revolutions. The model is for a community of about 2,000 people which aims to be as self-sufficient as possible by making use of both "low" and "high" technologies, the emphasis being on energy saving and preserving the quality of the environment. Electricity is supplied mainly from hydro and aerogenerators, transport within the village is by bicycle, horse and cart or on foot, as much local produce as possible is grown around the periphery of the village using labour intensive methods and waste recycling is done on site to produce clean water supplies and methane and other biogases. The village medical centre is designed to offer "alternative therapies" as well as modern medicine.

High-technology services come into their own when the village has to communicate with the rest of the world. Hence a community transport depot houses cars, lorries and vans for those needing to travel outside the village. But the most significant feature is the "cottage office" which houses a "resource centre" offering not only telephones, telexes, photocopying machines and secretarial and accounting services for local businesses, but also television with teletext, Viewdata and other link-up services for worldwide electronic communication. This acknowledgement of the microelectronics age also means that the village can offer educational facilities for all age groups.

Small-scale industry, for producing goods for sale outside the community as well as within it, is based on a mixture of high and low technologies. Few inhabitants would have only one job, the idea being to create job fulfilment by blurring the distinction between work and leisure and engaging people in different tasks at different times. Most people, for example, would spend quite a bit of time farming the green belt surrounding the village or digging their allotments, in addition to their main job. One of the main criteria for using high, labour-saving technology would be the elimination of boring and repetitive tasks.

It is unlikely that the model village will ever become a reality. But some of the ideas and detailed design work that have gone into creating it may be useful in less ambitious projects to build real futuristic societies. The Town and Country Planning Association and Greentown Group, for example, are currently looking for a site to build a small futuristic community of houses and small businesses. And Milton Keynes has already shown an interest in building such a community on a 25 acre site just outside the town.

Judy Redfearn 